\title{
Predicting visual information during sentence processing: Toddlers activate an object's shape before it is mentioned
}

\author{
Susan C. Bobb ${ }^{\mathrm{a}, *}$, Falk Huettig ${ }^{\mathrm{b}, \mathrm{c}}$, Nivedita Mani $^{\mathrm{d}}$

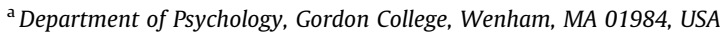 \\ ${ }^{\mathrm{b}}$ Max Planck Institute for Psycholinguistics, 6525 XD Nijmegen, The Netherlands \\ ${ }^{\mathrm{c}}$ Donders Institute for Brain, Cognition, and Behaviour, Radboud University Nijmegen, 6525 EZ Nijmegen, The Netherlands \\ d “Psychology of Language” Research Group, University of Göttingen, D-37073 Göttingen, Germany
}

\section{A R T I C L E I N F O}

\section{Article history:}

Available online 11 December 2015

\section{Keywords:}

Shape

Prediction

Spoken word recognition

Eye movements

Priming

Intermodal preferential looking

\begin{abstract}
A B S T R A C T
We examined the contents of language-mediated prediction in toddlers by investigating the extent to which toddlers are sensitive to visual shape representations of upcoming words. Previous studies with adults suggest limits to the degree to which information about the visual form of a referent is predicted during language comprehension in low constraint sentences. Toddlers (30-montholds) heard either contextually constraining sentences or contextually neutral sentences as they viewed images that were either identical or shape-related to the heard target label. We observed that toddlers activate shape information of upcoming linguistic input in contextually constraining semantic contexts; hearing a sentence context that was predictive of the target word activated perceptual information that subsequently influenced visual attention toward shape-related targets. Our findings suggest that visual shape is central to predictive language processing in toddlers.
\end{abstract}

() 2015 Elsevier Inc. All rights reserved.

\footnotetext{
* Corresponding author.

E-mail address: susan.bobb@gordon.edu (S.C. Bobb).
} 


\section{Introduction}

There is strong support that adults activate visual information about words' referents during auditory sentence processing (Huettig \& Altmann, 2007, 2011). Similarly, when children hear a word, they will look not only at the intended object but also to an object that is visually similar to the intended referent (Johnson \& Huettig, 2011; Johnson, McQueen, \& Huettig, 2011; Mani, Johnson, McQueen, \& Huettig, 2013). Adults and children also anticipate upcoming information during sentence comprehension. Studies show that even before a referent is named, the listener is able to use given contextual information to zero in on the upcoming referent. This ability to pre-activate, or predict upcoming information, is thought to facilitate language comprehension and production (Altmann \& Mirković, 2009; Chang, Dell, \& Bock, 2006; DeLong, Urbach, \& Kutas, 2005; Federmeier, 2007; Huettig, 2015; Pickering \& Garrod, 2007, 2013). In the current study, we further addressed the extent to which the upcoming spoken input is pre-activated during language comprehension by asking whether toddlers also activate shape information related to their predictions.

Indeed, a large body of evidence supports the idea that humans predict the language of others. Previous research has shown that both adults and children anticipate referents based on information such as the functional attributes implied by a preceding verb; on hearing "eat," they will look to the image of an edible object such as a cake (Altmann \& Kamide, 1999; Mani \& Huettig, 2012). Listeners also predict grammatical gender (Lew-Williams \& Fernald, 2007; Wicha, Moreno, \& Kutas, 2004) and phonological forms (DeLong et al., 2005) of upcoming words. In the adult literature, however, there is conflicting evidence about the extent to which shape information is pre-activated.

In a seminal study on language-mediated attention, Huettig and Altmann (2007) investigated how shape information mediates the interaction of concepts activated by spoken words and visual objects. Participants viewed a display of four unrelated objects depicted as line drawings while listening to a sentence. The sentence was either neutral or semantically biased toward one of the pictures. For instance, participants might see a picture of a barrel, pillow, rug, and snake while hearing the biasing sentence "In the beginning, the zookeeper worried greatly, but then he looked at the snake and realized that it was harmless." In semantically biased sentences, on hearing the target word snake, adult participants looked more to the target object (e.g., the snake) than to any of the other three distracters. But could participants predict the upcoming target word based on the preceding information in the sentence? Indeed, participants were already looking at the image of the snake on hearing the semantically related concept zookeeper, so even before hearing the target word snake, indicating that semantic information about the target objects had been activated in anticipation of hearing the specific word. In another display, the picture of the target (e.g., the snake) was replaced with a visually similar image (e.g., a picture of a cable). In this condition, adult participants also looked more to the visually similar object (e.g., a cable) than to the distracter images on hearing the target word (e.g., snake). Importantly, however, in the displays where the snake was replaced with the visually similar cable, hearing semantically related concepts such as zookeeper did not bias looks to the cable, suggesting limits to the extent to which information about the visual form of a referent is predicted during language comprehension in adults.

In situations where the context highly constrains potential referents, however, visual information appears to be pre-activated for adults. Rommers, Meyer, Praamstra, and Huettig (2013) tracked the eye movements of participants as they listened to highly predictive sentences such as "In 1969 Neil Armstrong was the first man to set foot on the moon." Before they heard the critical target word moon, participants were shown a display with three distracter objects and a critical object that was either unrelated (rice), identical (moon), or related in shape (tomato) to the target (moon). Identical and shape-related objects were fixated more often compared with the unrelated control object, suggesting that listeners had pre-activated not just linguistic information consistent with the input so far but also shape information related to their predictions. The authors obtained converging evidence for this interpretation in an event-related potential (ERP) experiment with the same materials (Rommers et al., 2013, Experiment 2). However, we note that-even when provided with highly constraining semantic contexts-the size of the shape effect is small, albeit significant (see Rommers, Meyer, \& Huettig, 2015, for a recent replication), suggesting that the extent to which shape information related 
to thematically appropriate continuations is pre-activated is open to debate even in such highly constraining semantic contexts.

Similarly, in a magnetoencephalographic (MEG) study, Dikker and Pylkkänen (2011) examined the extent to which violations of lexical predictions can influence early sensory processing by showing participants highly or weakly constraining images (e.g., an apple or a shopping bag) before examining participants' processing of target labels consistent with the presented image (e.g., "the apple"). They found a modulation of the visual M100 component by strength of the context provided by the image primes. These authors suggested that the brain generates form expectations based on lexical predictions only in highly constrained contexts, for example, when participants see an image of an apple before viewing the word "apple" but not when participants see an image of a shopping bag before viewing the word "apple." Taken together, these studies suggest that, in adult language processing, prediction can involve early visual representations, but only in situations where the context narrows prediction to one particular word.

How do concepts of spoken words and visual objects interact in a toddler's mind? In the current study, we examined whether language-mediated attention in toddlers, similar to adults, can be guided by visual shape relations. More specifically, we examined whether, similar to adult results in highly constraining sentence contexts (Rommers et al., 2013, 2015), a semantically related prime can bias toddler looks toward a shape competitor, suggesting an important role for shape information in child language processing.

Why might toddlers exhibit early sensitivity to shape information? Previous research has noted a shape bias in children whereby children extend the label of a known noun to other objects that are similar in shape (e.g., Landau, Smith, \& Jones, 1988). Bowerman (1978) reported the case of a child who used the word "moon" to refer to a half grapefruit and the dial on a dishwasher. Clark (1973) described a child who used the word "apple" to refer to a doorknob. Why might this be? Bloom (1973) initially suggested that children observe the similarity between these objects (e.g., the shape of an apple and the shape of a doorknob). She argued that these cases show that children are reasoning along the lines of "I know about apples, that thing is not an apple, I don't know what to call it, but it's like an apple" (p. 79). Current research on the role of shape in word learning highlights at least two potential roles for shape in world learning. According to shape-as-cue accounts, shape functions as a cue to identify a kind of object and highlights conceptual categories (Booth \& Waxman, 2002a,b; Diesendruck \& Bloom, 2003). On the other hand, attentional learning accounts emphasize a system of learned associations that dynamically changes in response to attentional biases shaped by perceptual experience and statistical regularities (Colunga \& Smith, 2008). Although the theories diverge as to the extent to which both perceptual information and conceptual information contribute to word learning, they appear to agree that children integrate perceptual and linguistic information in the acquisition of words.

Cue validity may be a critical component as to why shape features prominently in word learning. Indeed, research on object categorization in infants has demonstrated a hierarchy to the featural information that infants preferentially use (Diesendruck \& Bloom, 2003; see also Samuelson \& Smith, 1999). Diesendruck and Bloom (2003) showed that 2- and 3-year-olds use shape over color or texture in both novel object label learning and categorization. Surface features such as color may be less relevant because they function as arbitrary features that do not contribute to the object's identity. In contrast, shape strongly predicts basic object categories, which also happen to be categories that are the earliest sorted and named by children (Rosch, Mervis, Gray, Johnson, \& Boyes-Braem, 1976). Therefore, toddlers may rely on features such as shape to more reliably identify, categorize, or reason about objects.

Children's increased attention to shape could contribute in part to their rate of noun acquisition (Gershkoff-Stowe \& Smith, 2004). Gershkoff-Stowe and Smith (2004) showed that the first 25 nouns children acquired tended to share shape similarity and that as children's vocabulary increased, so did their attention to shape in naming tasks. As their attention to shape increased, so did their rate of noun acquisition outside the laboratory, suggesting a synergistic relationship between shape sensitivity and vocabulary growth where each builds on the other. If this were true, then as other cues increase in relevance, and as children learn about other kinds of concepts and words, the dependence on shape would decrease. 
But do adults continue to exhibit a shape bias? Whereas some studies seem to indicate a continued reliance on shape, others show a move to an increased reliance on object function over object shape with age under conditions where the object's function is highlighted (Graham, Williams, \& Huber, 1999; Kemler Nelson, 1995). Smith, Jones, and Landau (1996) showed that 3-year-olds were influenced by shape when naming objects but judged similarity between objects based on function. Adults, on the other hand, named objects and judged similarities based on function. This developmental shift from shape to function occurs relatively early; whereas 2-year olds are able to label objects by functions (Kemler Nelson, Russell, Duke, \& Jones, 2000), Merriman, Scott, and Marazita (1993) showed that 3- and 4-year olds typically still extended novel words to novel objects on the basis of appearance. By 6 years of age, however, they did this on the basis of function at a level greater than chance.

The current study makes an important contribution to understanding the scope of language prediction in children by investigating shape information during online language processing, a type of representation that has not yet been investigated with respect to language prediction in children. Although previous studies suggest that shape information figures prominently in the developing lexicon and may even support word learning by cuing the category of objects (e.g., Graham \& Diesendruck, 2010), these studies have not addressed how shape information informs the online language processing of children. During word recognition, children have been shown to retrieve perceptual information associated with a heard word, which is thought to support the mapping of the visual world onto lexical candidates (Johnson \& Huettig, 2011; Johnson et al., 2011; Mani et al., 2013). Coactivating the shape of an object may similarly help children to locate a referent in the visual world. Evidence to this effect provides a possible avenue for the emergence of the observed shape bias while more importantly addressing the extent of information that is predicted during language processing. Do toddlers pre-activate shape information as language unfolds?

To investigate the role of visual shape information in toddlers' lexical processing, we adapted the methods of Huettig and Altmann (2007). Note that the design of Huettig and Altmann was simplified in the sense that only two pictures, instead of four pictures, were presented to the toddlers. Analogous to Huettig and Altmann, however, the target picture was never paired with a picture of the shape distracter. Children saw images of two familiar objects presented side by side and then heard a sentence. Primed sentences created a biasing context toward the target object (SHOVEL), for example, "The boy gets his bucket and then his new shovel." Neutral sentences created no bias towards the target picture (SHOVEL) before hearing the target label, for example, "The boy gets his hat and then his new shovel." Neutral and primed sentences were paired with target-distracter images to create four experimental conditions. In the Primed Identity condition, children heard a related prime (bucket) sentence with an identity target image (SHOVEL). In the Neutral Identity condition, children heard an unrelated prime (hat) sentence with identity target image (SHOVEL) and an unrelated distracter (GLASSES). In the Primed Shape condition, children heard the related prime (bucket) sentence with the shape-related target image (FORK). In the Neutral Shape condition, children heard the same unrelated prime (hat) sentence with a shape-related target image (FORK). See Table 1 for a condition overview.

We analyzed the proportion of target looking across three time windows: (a) a baseline window before the prime (hat) onset, (b) a prime window from prime onset to target (SHOVEL) onset, and

Table 1

Overview of the four experimental conditions.

\begin{tabular}{llll}
\hline Condition & Auditory sentence & Target image & Distracter image \\
\hline \multirow{3}{*}{ Neutral Identity } & \multicolumn{1}{c}{ Prime } & Target \\
& $\begin{array}{l}\text { Der Junge holt seinen Hut und dann seine neue Schaufel } \\
\text { The boy gets his hat and then his new shovel }\end{array}$ & $\begin{array}{l}\text { Schaufel } \\
\text { shovel }\end{array}$ & $\begin{array}{l}\text { Brille } \\
\text { glasses }\end{array}$ \\
Primed Identity & $\begin{array}{l}\text { Der Junge holt seinen Eimer und dann seine neue Schaufel } \\
\text { The boy gets his bucket and then his new shovel }\end{array}$ & Schaufel & Brille \\
Neutral Shape & Der Junge holt seinen Hut und dann seine neue Schaufel & Gabel & glasses \\
& The boy gets hille hat and then his new shovel & fork & glasses \\
Primed Shape & Der Junge holt seinen Eimer und dann seine neue Schaufel & Gabel & Brille \\
& The boy gets his bucket and then his new shovel & fork & glasses \\
\hline
\end{tabular}

Note. The table illustrates sample trials across four critical conditions: (a) Neutral Identity, (b) Primed Identity, (c) Neutral Shape, and (d) Primed Shape. 
(c) a target window occurring from target label onset. On the basis of previous developmental research, we anticipated that related primes (bucket) would induce a bias toward the target image (SHOVEL) (Arias-Trejo \& Plunkett, 2009; Johnson et al., 2011). Crucially, if a biasing sentence context involves pre-activation of shape information for toddlers, we also anticipated that related primes (bucket) would bias looks toward shape-related images (FORK) of predicted words (i.e., SHOVEL). In other words, we asked whether, on hearing the sentence "The boy gets his bucket and then his new ...," toddlers (a) pre-activate upcoming information consistent with the sentence so far (i.e., preactivate the related word "shovel") and (b) pre-activate shape information related to their predications and fixate shape-matching competitors (e.g., fork) on hearing the prime word "bucket" (because forks and shovels have a similar global visual form).

\section{Method}

\section{Participants}

The participants were 28 children (12 female) at 30 months of age ( $M=29 ; 17$ [months;days], range $=29 ; 10-30 ; 27$ ). We tested an additional 7 children but excluded them from the final sample due to failure to look at more than $50 \%$ of the trials $(n=2)$, external distractions during the experiment $(n=2)$, or refusal to participate $(n=3)$. All children had no known visual or hearing difficulties and came from homes where German was the main language in use. Children received a small book for taking part in the study.

\section{Stimuli}

We first chose 12 German words as critical targets. For each target (e.g., Schaufel "shovel"), we chose a semantically related prime (e.g., Eimer "bucket") based on the Weber Noun Associations for German database (http://www.coli.uni-saarland.de/projects/nag/). Targets were listed as a frequent first response to our semantically related prime as stimulus to ensure a strong forward association from prime to target. Each critical target was then paired with an unrelated prime (e.g., Hut "hat") that was not associated with the target. For each critical target, we chose a target image that depicted a prototypical instance of the target (e.g., Schaufel "shovel"), a shape-related target image (e.g., Gabel "fork"; both shovels and forks have a similar prototypical global shape), and an unrelated distracter image (e.g., Brille "glasses") that did not share any shape similarity with the target. The identity, shape, and distracter images did not share phonological onset, did not share typical color, were not animate, and were not from the same semantic category, but they did share the same gender and plurality. We then embedded primes and targets into carrier sentences with similar grammatical structures (e.g., Der Junge holt seinen Eimer und dann seine neue Schaufel. "The boy gets his bucket and then his new shovel."). Note that target and distracter pairs were always the same across conditions so that any differences between conditions cannot be attributed to the differences between target and distracter.

We arranged sentences and target-distracter pairs to create four experimental conditions. In the Primed Identity condition, we paired the related prime (Eimer "bucket") with the identity target image (Schaufel "shovel"), anticipating that the related prime would induce a bias toward the target image even before participants heard the target label. In the Neutral Identity condition, we paired the unrelated prime (Hut "hat") with the identity target image (Schaufel "shovel") so that sentences would not bias toddlers toward the target picture before hearing the target image label. We expected that participants, on hearing the target label, would look toward the target image in both the Neutral Identity and Primed Identity conditions. In the Primed Shape condition, we paired the related prime (Eimer "bucket") with the shape-related target image (Gabel "fork"), anticipating that the related prime would induce a bias toward the shape-related target image even before participants heard the target label. In the Neutral Shape condition, we paired the unrelated prime (Hut "hat") with the shape-related target image (Gabel "fork"). See the Appendix for the complete list of stimuli. 
A female native speaker of German produced the speech stimuli in a child-directed manner. We recorded stimuli using Adobe Audition software at a sampling rate of $44.1 \mathrm{kHz}$ and subsequently edited stimuli using Goldwave and PRAAT for acoustic measurements.

\section{Item validation}

To ensure that stimuli pairings were accurately matched with respect to shape similarity, we conducted an item validation study. Specifically, we wanted to ensure that typical referents of the prime words did not overlap in shape with target and distracter pictures. We also did not want the referents of the target words and distracter pictures to overlap in shape. However, it is essential to the planned manipulation that typical referents of the target words and the actually presented target images strongly overlapped in shape, whereas typical referents of the target words and the presented shape-overlapping images were also intended to overlap in shape.

We asked 23 native German speakers ( 22 female, mean age $=23$ years, range $=20-34$ ) to take part in the norming study. Participants were presented with the individual prime and target words and saw the planned picture stimulus (i.e., the target image, the shape-related target image, or the unrelated distracter image). For instance, for the primed sentence "Der Junge holt seinen Eimer und dann seine neue Schaufel" (The boy gets his bucket and then his new shovel), participants would see the word "Eimer" (bucket, related prime), "Hut" (hat, neutral prime), or "Schaufel" (target, shovel) and see an image of a shovel (target image), a fork (shape-related distracter), or glasses (unrelated distracter). They then rated how similar in shape the typical referent of the presented word and the presented image were. Participants were asked to use a scale from 0 (keine Form-Ähnlichkeit, "no similarity in physical shape") to 7 (identisch in Form, "identical in physical shape"). Table 2 shows mean ratings for all of the word-picture pairings.

For each pair, we analyzed whether the mean rating was above or below the intermediate rating of 3.5 (see Arias-Trejo \& Plunkett, 2010, for similar analyses). All ratings were in the anticipated direction; referents of the neutral prime words were rated not similar in shape to target/ shape-related/distracter images (significantly <3.5). Similarly, referents of the related prime words were rated not similar in shape to target/shape-related/distracter images (significantly <3.5) and referents of the target words were also rated not similar in shape to distracter images ( significantly $<3.5$ ).

Crucial for the experimental manipulation, however, we found that referents of the target labels were rated as highly similar to the presented target images. Furthermore, referents of the target labels were rated as highly visually similar to the presented shape-related images. Thus, the chosen target images were highly typical referents of the target labels and overlapping in shape with the shaperelated picture pairs, thereby validating the choice of stimuli for the main experiment.

Table 2

Norming study mean scores.

\begin{tabular}{lllll}
\hline Word & Picture & Mean score & $S D$ & $p$-Value \\
\hline Neutral prime & Distracter & 0.44 & 0.61 & $<.001$ \\
Neutral prime & Identity & 0.37 & 0.50 & $<.001$ \\
Neutral prime & Shape & 0.40 & 0.46 & $<.001$ \\
Related prime & Distracter & 0.24 & 0.37 & $<.001$ \\
Related prime & Identity & 1.30 & 0.83 & $<.001$ \\
Related prime & Shape & 0.71 & 0.66 & $<.001$ \\
Target & Distracter & 0.63 & 0.70 & $<.001$ \\
Target & Identity & 6.95 & 0.10 & $<.001$ \\
Target & Shape & 4.39 & 1.02 & $<.001$
\end{tabular}

Note. Mean scores (on a scale from 0 to 7) of the norming study for words in the priming sentence (neutral, related, or target) and for picture stimuli (distracter, identity, or shape related). The $p$-values indicate significance from the intermediate rating (3.5), where mean scores below 3.5 indicate shape dissimilarity and scores above 3.5 indicate shape similarity. 
Procedure

The child sat on the caregiver's lap during the experiment facing a television monitor $(92 \times 50 \mathrm{~cm})$ at eye level. The child was approximately $100 \mathrm{~cm}$ away from the monitor. We recorded the child's eye movements via two cameras mounted above the monitor. A digital splitter routed synchronized signals from the two cameras to create a recording of two separate time-locked images of the child. We presented auditory stimuli over centrally located loudspeakers above the monitor. The caregiver listened to music over headphones so as not to bias the child's behavior.

\section{Design}

We presented children with 12 trials, namely 3 trials in each of four critical conditions: (a) Primed Identity, (b) Neutral Identity, (c) Primed Shape, and (d) Neutral Shape. At the start of each trial, children saw images of two familiar objects presented side by side. Objects remained on the screen for the duration of the 9000-ms trial. Children then heard a sentence (e.g., Der Junge holt seinen Eimer und dann seine neue Schaufel. "The boy gets his bucket and then his new shovel."). Each sentence was time-locked so that at $2100 \mathrm{~ms}$ into the trial children heard the potential prime phrase (e.g., den Eimer). The onset of the prime divided the trial into a baseline phrase and a prime phase, where the baseline phase provided an index of children's baseline preference for either of the picture pairs, which we subsequently used for comparison with the prime phase. At a variable time in the sentence, children were presented with the target label (e.g., Schaufel), which marked the onset of the target phase of the trial. Each child saw a given target or distracter image only once during the experiment. Targets appeared equally often to the left and to the right, and we randomized the order of trial presentation.

\section{Analysis}

Trained coders coded video data collected from the children offline on a frame-by-frame basis at 40-ms intervals using Look (Meints \& Woodford, 2008; interrater reliability with a second skilled coder, $r=.99$ ). We then aggregated data across three time windows. In the first time window, the baseline window, we computed fixations occurring $1000 \mathrm{~ms}$ before the prime noun onset (Eimer "bucket") to establish children's baseline preference for either of the images presented on-screen (see Johnson et al., 2011, and Mani et al., 2013, for similar baseline windows). In the second time window, the prime window, we computed fixations occurring from the onset of the prime word (Eimer "bucket") to the onset of the target word (Shaufel "shovel"). The duration of this window varied based on the onset of the target label and ranged from 2605 to $3894 \mathrm{~ms}$. In the third window, the target window, we computed fixations occurring from the onset of the target word to $2000 \mathrm{~ms}$ from the onset of this target word (cf. Mani \& Plunkett, 2007, 2010, 2011; Swingley, Pinto, \& Fernald, 1999). For each window, we determined the proportion of time children looked at the target (PTL) by dividing the time spent looking at the target $(\mathrm{T})$ by the time spent looking at the target and the distracter $(\mathrm{T}+\mathrm{D})$. We analyzed only trials on which children looked to both the target and distracter images during the pre-naming phase to ensure that children viewed the entire visual array before responding to the experimental sentence. A total of 27 trials were excluded (7.2\% of trials; see Mani \& Plunkett, 2010, for similar exclusion criteria). Each child's looking times were then aggregated by condition to create a participant mean per condition per window.

\section{Results}

In Figs. 1 and 2, we have plotted the proportion of target fixations in each of the three time windows. Note that we plotted fixations for average baseline, prime, and target windows. Because target label onset varied between trials, actual analyses were done based on the individual onset of target noun labels for each trial. The critical comparison between the Primed Identity and Neutral Identity conditions shows increased looks to targets for the Primed Identity condition over the Neutral Identity 


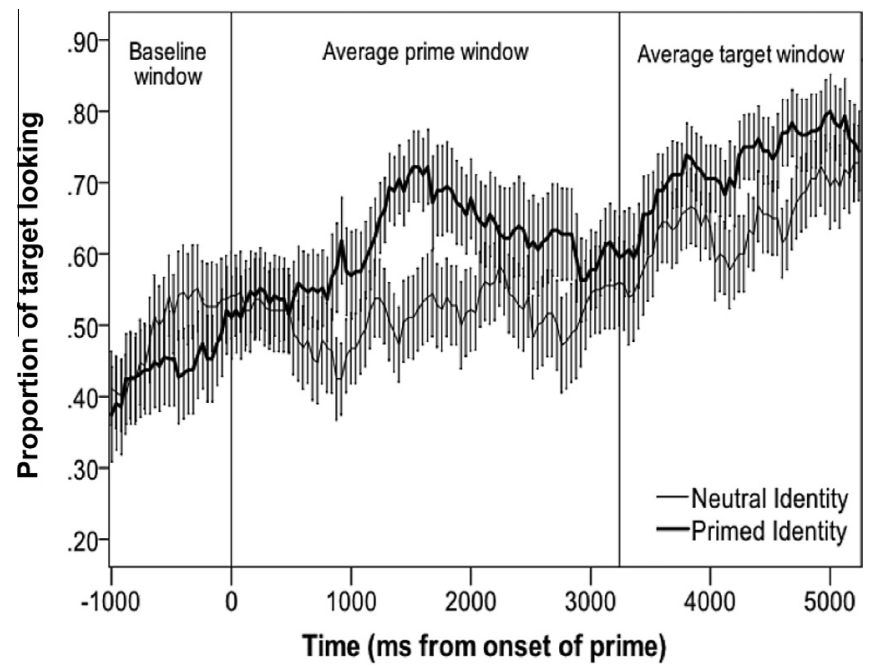

Fig. 1. Time course of proportion of target looking ( $\pm 1 \mathrm{SE}$ ) across baseline, prime, and target windows for Neutral Identity (N_ID) and Primed Identity (P_ID) conditions.

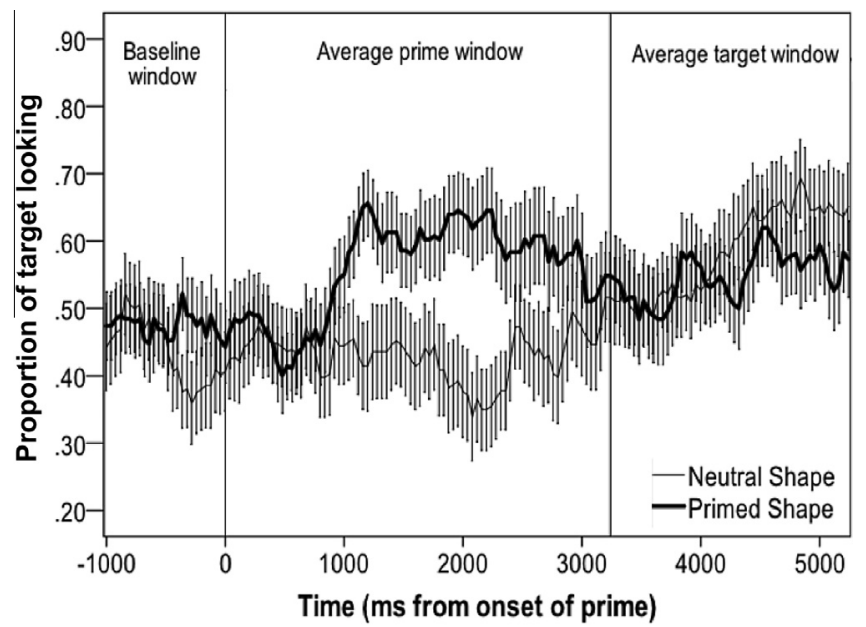

Fig. 2. Time course of proportion of target looking ( $\pm 1 \mathrm{SE}$ ) across baseline, prime, and target windows for Neutral Shape (N_S) and Primed Shape (P_S) conditions.

condition in the prime phase, and this trend continues into the target phase. Importantly, the critical comparison between the Primed Shape and Neutral Shape conditions also shows increased looks to targets for the Primed Shape condition over the Neutral Shape condition, but only in the prime phase. In what follows, we separate the data by windows to examine the difference between conditions in each window (cf. Mani et al., 2013).

\section{Baseline window}

A 2 (Priming: Neutral or Primed) $\times 2$ (Target: Identity or Shape) repeated measures analysis of variance (ANOVA) revealed no main effects of priming, $F(1,27)=0.18, p>.50$, or condition, $F(1,27)=0.42$, $p>.50$, or interactions between priming and target, $F(1,27)=0.01, p>.50$. Despite the absence of the 
interaction, we ran planned comparisons to ensure that there were no significant differences in target fixations between conditions in the baseline window (all $p s>.60$ ).

\section{Prime window}

A 2 (Priming: Neutral or Primed) $\times 2$ (Target: Identity or Shape) repeated measures ANOVA revealed a main effect of priming, $F(1,27)=15.22, p=.001, \eta_{\mathrm{p}}^{2}=.36$, and target, $F(1,27)=7.99$, $p=.009, \eta_{\mathrm{p}}^{2}=.23$, and no interaction between priming and target $(p=.471)$. Thus, regardless of whether the target object in primed trials was semantically related to the prime or shape related to a semantic associate of the prime, there were significant differences between primed and neutral trials. In other words, there was an equally strong priming effect for shape-related and identity targets. On the other hand, regardless of priming condition, there were significant differences between identity and shape trials, with a larger proportion of target looking in the Identity condition than in the Shape condition. Despite the absence of the interaction, we ran planned comparisons to ensure that the effect of priming was indeed significant between identity and shape-related trials and found that toddlers fixated the target significantly more in Primed Identity trials than in Neutral Identity trials, $t$ $(27)=2.17, p=.039, d=0.61$. Importantly, children also fixated the target more in Primed Shape trials than in Neutral Shape trials, $t(27)=3.24, p=.003, d=0.75$.

\section{Target window}

A 2 (Priming: Neutral or Primed) $\times 2$ (Target: Identity or Shape) repeated measures ANOVA revealed a main effect of target, $F(1,27)=4.77, p=.038, \eta_{\mathrm{p}}^{2}=.15$, but no main effect of priming or interaction between priming and target $(p s>.15$ ). In other words, the relationship between the target and the prime did not modulate responding once the target label was mentioned. However, as expected, participants fixated the target object more when the target label referred to this object rather than when the referent of the label was merely shape-related to this object. Despite the absence of the interaction, we ran planned comparisons, which found no significant differences in the proportion of target looking for our critical comparisons ( $p s>.10$ ). We did, however, find that participants looked more at the target in primed trials when the target label referred to the target object (primed identity trials) relative to when the referent of the target label was merely shape-related to the target object, $t$ $(27)=2.69, p=.012, d=0.72$. This comparison was not significant in neutral trials $(p=.863)$.

\section{Discussion}

In the current study, we investigated whether toddlers pre-activate visual shape properties related to upcoming linguistic information during language processing in the visual world. The findings of the current study suggest an important role for shape information retrieved during children's prediction of upcoming input in spoken language processing. Here we demonstrated that toddlers activate shape information of upcoming linguistic input in semantically constraining sentence contexts.

What specific purpose does predictive shape activation serve? Recent research highlights the multimodality of language processing in infants and adults (Mani \& Schneider, 2013; Yeung \& Nazzi, 2014; Yeung \& Werker, 2009). This work shows that, just as language can influence visual categorization of objects in the world, visual information can help to structure language processing. For instance, research on children's word recognition shows that young children retrieve perceptual information associated with the referent of a word on hearing this word (Arias-Trejo \& Plunkett, 2009; Johnson \& Huettig, 2011; Johnson et al., 2011; Mani et al., 2013). Such findings are typically explained by suggesting that co-activation of perceptual information may help children to quickly find a match for a heard word in their visual environment. Similarly, Yeung and Werker (2009) showed that merely teaching infants the association between two differently shaped objects and two sounds helps infants to better discriminate the sounds from one another (see Mani \& Schneider, 2013, for similar results with speaker-sound pairings). Applying this idea to infants' learning of words, infants may retrieve shape information associated with familiar words so as to better retrieve conceptual information 
associated with these words during language processing. Indeed, infants synchronize interactions with their caregivers, including object tracking, at an early age (see Yu \& Smith, 2013, for a review). For the developing mental lexicon, activating a referent's shape attributes may support word learning by providing a particularly salient cue to object categories (Graham \& Diesendruck, 2010). Thus, for instance, Samuelson and Smith (2005) examined a corpus of spontaneous productions by children between 17 and 24 months of age in response to a set of Nonce objects and found that the names children produced reflected the shapes of the objects, suggesting that naming was cued by object shape and that attention to shape might not be lexically constrained. There appear to be sizable advantages to the co-activation of perceptual information associated with the referent of a word, at least on hearing this word.

Similarly, children's and adults' prediction of upcoming linguistic input may help the listener to keep up with the pace of spoken language by narrowing down the set of possible referents in a discourse. We suggest that children's prediction of shape information associated with spoken language input helps them to anticipate the focus of subsequent dialogue and locate this referent in the visual world. We propose, therefore, that children's pre-activation of shape information in predictive language processing scaffolds the mapping of anticipated language input onto the visual world.

Although the shape of an object appears to play a particularly predominant role in early language acquisition, this pre-activation of shape representations may be limited during adulthood (see Rommers et al., 2013, 2015, for relatively small effects of pre-activation of shape representations). In particular, Huettig and Altmann (2007) showed that adults do not preferentially fixate shaperelated competitors predicted by semantically constraining sentence contexts. Only when provided with highly constraining semantic contexts, such as "In 1969 Neil Armstrong was the first man to set foot on the ...," did they observe small, albeit significant, effects of shape overlap (Rommers et al., 2013). In contrast, here we showed robust effects that children do fixate shape competitors of the target shovel even before hearing the target word. Although adults and children alike predict upcoming linguistic information in such contexts, it is possible that shape representations associated with these predictions play an important role only early in development (as shown by the results of the current study). Shape effects during adulthood may appear early and rapidly decay simply because mature language users rely much less on such scaffolding. Thus, shape prediction would only figure centrally during periods of rapid language development. As such, the results we reported here could mark a possible difference with previous adult studies.

Based on the absence of context-mediated visual shape activation in their study, Huettig and Altmann (2007) ruled out the possibility of a mechanism in which the spoken input pre-activates a target visual shape representation (which is then matched to a shape-overlapping visual referent). They hypothesized instead that the visual input pre-activates multiple candidate lexical representations (cf. Mani \& Plunkett, 2010; McQueen \& Huettig, 2014; Meyer, Belke, Telling, \& Humphreys, 2007). The prior semantic context boosts activation of the target label, resulting in an increased likelihood that saccades are directed to the target object. The findings of the current study, in contrast, suggest that-at least during childhood-spoken language processing involves the pre-activation of not just linguistic information but also visual shape representations consistent with the input so far.

Note that our findings do not rule out the possibility of the alternative mechanism proposed above, namely one where multiple candidate lexical representations are activated on viewing the visual input. Indeed, our previous work strongly supports precisely such a mechanism, where infants and adults alike internally generate the labels of visually fixated images (Huettig \& McQueen, 2007; Mani \& Plunkett, 2010). We suggest, however, that interactions between language and the visual world are guided by multiple mechanisms, including mapping from the visual input onto candidate lexical representations as well as, as shown in the current study, mapping from pre-activated shape representations based on linguistic context onto the visual world (cf. Huettig, Mishra, \& Olivers, 2012).

In the current study, we presented toddlers with pictured images, and as a result toddlers may have been more likely to activate information about the referent's physical properties (Huettig \& McQueen, 2007, 2011). The heightened relevance of shape knowledge to the experimental environment may call into question the extent to which shape information is naturally pre-activated during lexical retrieval. Although recent ERP findings from the adult literature show that perceptual attributes can indeed be pre-activated in experimental environments where no pictures are used (Rommers et al., 2013), there 
is also some precedent in the infancy literature that experimental environments themselves can shift the salience of an object's attributes. Wilcox and Chapa (2004; see also Wilcox, Woods, \& Chapa, 2008) showed that young infants could be primed to attend to typically less preferred object features, thereby increasing how much they normally relied on the feature, when they were shown the feature's functional value in individuating objects. Future work with toddlers will need to clarify whether perceptual attributes are pre-activated in the absence of pictorial stimuli (cf. Smith, Yu, Yoshida, \& Fausey, 2015, for the use of head cameras to study infant visual experience). Future work will also need to confirm the current results with older children who have a larger vocabulary size to see whether results can be extended to a larger set of stimuli and to delineate the developmental trajectory of this shape bias (e.g., Borgström, von Koss Torkildsen, \& Lindgren, 2015).

In conclusion, our data reveal that toddlers can (a) pre-activate upcoming information consistent with the sentence so far (i.e., pre-activate the related word "shovel" on hearing a sentence such as "The boy gets his bucket and then his new ...") and (b) pre-activate shape information related to their predications and fixate shape-matching competitors (e.g., fork) on hearing the prime word "bucket." We also showed that semantically constraining contexts biased shape pre-activation effects; hearing a biasing sentence context predictive of the target word activated perceptual information that subsequently influenced visual attention toward shape-related targets. Thus, our results lead us to conclude that visual form is central to predictive language processing in toddlers.

\section{Acknowledgments}

This work was funded by the German Excellence Initiative (Institutional Strategy). We especially thank all of the toddlers and their parents who participated in this study.

\section{Appendix}

Stimuli used in study.

\begin{tabular}{|c|c|c|c|c|}
\hline Conditio & Sentence & $\begin{array}{l}\text { Identity } \\
\text { target }\end{array}$ & $\begin{array}{l}\text { Shape } \\
\text { target }\end{array}$ & Distracter \\
\hline Primed & $\begin{array}{l}\text { Das Mädchen bemerkt den Jungen und sucht seinen } \\
\text { kleinen Ball } \\
\text { The girl notices the boy and looks for his small ball }\end{array}$ & $\begin{array}{l}\text { Ball } \\
\text { ball }\end{array}$ & $\begin{array}{l}\text { Stein } \\
\text { stone }\end{array}$ & $\begin{array}{l}\text { Käse } \\
\text { cheese }\end{array}$ \\
\hline Neutral & $\begin{array}{l}\text { Das Mädchen bemerkt den Mann und sucht seinen } \\
\text { kleinen Ball } \\
\text { The girl notices the man and looks for his small ball }\end{array}$ & $\begin{array}{l}\text { Ball } \\
\text { ball }\end{array}$ & $\begin{array}{l}\text { Stein } \\
\text { stone }\end{array}$ & $\begin{array}{l}\text { Käse } \\
\text { cheese }\end{array}$ \\
\hline Primed & $\begin{array}{l}\text { Das Mädchen beobachtet die Nacht und sieht den } \\
\text { schönen Mond } \\
\text { The girl watches the night and sees the beautiful moon }\end{array}$ & $\begin{array}{l}\text { Mond } \\
\text { moon }\end{array}$ & $\begin{array}{l}\text { Stein } \\
\text { stone }\end{array}$ & $\begin{array}{l}\text { Topf } \\
\text { pot }\end{array}$ \\
\hline Neutral & $\begin{array}{l}\text { Das Mädchen beobachtet das Sofa und sieht den } \\
\text { schönen Mond } \\
\text { The girl watches the sofa and sees the beautiful moon }\end{array}$ & $\begin{array}{l}\text { Mond } \\
\text { moon }\end{array}$ & $\begin{array}{l}\text { Stein } \\
\text { stone }\end{array}$ & $\begin{array}{l}\text { Topf } \\
\text { pot }\end{array}$ \\
\hline Primed & $\begin{array}{l}\text { Das Mädchen geht zum Ofen und sieht die große } \\
\text { Pizza } \\
\text { The girl goes to the oven and sees the large pizza }\end{array}$ & $\begin{array}{l}\text { Pizza } \\
\text { pizza }\end{array}$ & $\begin{array}{l}\text { Uhr } \\
\text { clock }\end{array}$ & $\begin{array}{l}\text { Bürste } \\
\text { brush }\end{array}$ \\
\hline Neutral & $\begin{array}{l}\text { Das Mädchen geht zur Schaukel und sieht die große } \\
\text { Pizza } \\
\text { The girl goes to the swing and sees the large pizza }\end{array}$ & $\begin{array}{l}\text { Pizza } \\
\text { pizza }\end{array}$ & $\begin{array}{l}\text { Uhr } \\
\text { clock }\end{array}$ & $\begin{array}{l}\text { Bürste } \\
\text { brush }\end{array}$ \\
\hline Primed & $\begin{array}{l}\text { Das Mädchen holt das Handtuch und sucht die neue } \\
\text { Seife } \\
\text { The girl gets the hand towel and looks for the new soap }\end{array}$ & Seife & $\begin{array}{l}\text { Butter } \\
\text { butter }\end{array}$ & $\begin{array}{l}\text { Nase } \\
\text { nose }\end{array}$ \\
\hline
\end{tabular}


Appendix (continued)

\begin{tabular}{|c|c|c|c|c|}
\hline \multicolumn{2}{|c|}{ Condition Sentence } & \multirow{2}{*}{$\begin{array}{l}\begin{array}{l}\text { Identity } \\
\text { target }\end{array} \\
\text { Seife } \\
\text { soap }\end{array}$} & \multirow{2}{*}{$\begin{array}{l}\text { Shape } \\
\text { target } \\
\text { Butter } \\
\text { butter }\end{array}$} & \multirow{2}{*}{$\begin{array}{l}\text { Distracter } \\
\text { Nase } \\
\text { nose }\end{array}$} \\
\hline Neutral & $\begin{array}{l}\text { Das Mädchen holt den Teddy und sucht die neue } \\
\text { Seife } \\
\text { The girl gets the teddy bear and looks for the new soap }\end{array}$ & & & \\
\hline Primed & $\begin{array}{l}\text { Das Mädchen sieht die Tasse und holt einen neuen } \\
\text { Löffel } \\
\text { The girl sees the cup and gets a new spoon }\end{array}$ & $\begin{array}{l}\text { Löffel } \\
\text { spoon }\end{array}$ & $\begin{array}{l}\text { Besen } \\
\text { broom }\end{array}$ & $\begin{array}{l}\text { Kamm } \\
\text { comb }\end{array}$ \\
\hline Neutral & $\begin{array}{l}\text { Das Mädchen sieht die Decke und holt einen neuen } \\
\text { Löffel } \\
\text { The girl sees the blanket and gets a new spoon }\end{array}$ & $\begin{array}{l}\text { Löffel } \\
\text { spoon }\end{array}$ & $\begin{array}{l}\text { Besen } \\
\text { broom }\end{array}$ & $\begin{array}{l}\mathrm{Kamm} \\
\mathrm{comb}\end{array}$ \\
\hline Primed & $\begin{array}{l}\text { Das Mädchen zeigt auf die Wolke und dann auf die } \\
\text { gelbe Sonne } \\
\text { The girl points at the cloud and then the yellow sun }\end{array}$ & $\begin{array}{l}\text { Sonne } \\
\text { sun }\end{array}$ & $\begin{array}{l}\text { Uhr } \\
\text { clock }\end{array}$ & $\begin{array}{l}\text { Tür } \\
\text { door }\end{array}$ \\
\hline Neutral & $\begin{array}{l}\text { Das Mädchen zeigt auf den Becher und dann auf die } \\
\text { gelbe Sonne } \\
\text { The girl points at the cup and then the yellow sun }\end{array}$ & $\begin{array}{l}\text { Sonne } \\
\text { sun }\end{array}$ & $\begin{array}{l}\text { Uhr } \\
\text { clock }\end{array}$ & $\begin{array}{l}\text { Tür } \\
\text { door }\end{array}$ \\
\hline Primed & $\begin{array}{l}\text { Der Junge hat den Schal und sucht die große Mütze } \\
\text { The boy has the scarf and looks for the large cap }\end{array}$ & $\begin{array}{l}\text { Mütze } \\
\text { cap }\end{array}$ & $\begin{array}{l}\text { Erdbeere } \\
\text { strawberry }\end{array}$ & $\begin{array}{l}\text { Blume } \\
\text { flower }\end{array}$ \\
\hline Neutral & $\begin{array}{l}\text { Der Junge hat den Bus und sucht die große Mütze } \\
\text { The boy has the bus and looks for the large cap }\end{array}$ & $\begin{array}{l}\text { Mütze } \\
\text { cap }\end{array}$ & $\begin{array}{l}\text { Erdbeere } \\
\text { strawberry }\end{array}$ & $\begin{array}{l}\text { Blume } \\
\text { flower }\end{array}$ \\
\hline Primed & $\begin{array}{l}\text { Der Junge holt seinen Eimer und dann seine neue } \\
\text { Schaufel } \\
\text { The boy gets his bucket and then his new shovel }\end{array}$ & $\begin{array}{l}\text { Schaufel } \\
\text { shovel }\end{array}$ & $\begin{array}{l}\text { Gabel } \\
\text { fork }\end{array}$ & $\begin{array}{l}\text { Brille } \\
\text { glasses }\end{array}$ \\
\hline Neutral & $\begin{array}{l}\text { Der Junge holt seinen Hut und dann seine neue } \\
\text { Schaufel } \\
\text { The boy gets his hat and then his new shovel }\end{array}$ & $\begin{array}{l}\text { Schaufel } \\
\text { shovel }\end{array}$ & $\begin{array}{l}\text { Gabel } \\
\text { fork }\end{array}$ & $\begin{array}{l}\text { Brille } \\
\text { glasses }\end{array}$ \\
\hline Primed & $\begin{array}{l}\text { Der Junge putzt die Spüle und holt den kleinen Teller } \\
\text { The boy cleans the sink and gets the small plate }\end{array}$ & $\begin{array}{l}\text { Teller } \\
\text { plate }\end{array}$ & $\begin{array}{l}\text { Keks } \\
\text { cookie }\end{array}$ & $\begin{array}{l}\text { Socken } \\
\text { sock }\end{array}$ \\
\hline Neutral & $\begin{array}{l}\text { Der Junge putzt das Radio und holt den kleinen Teller } \\
\text { The boy cleans the radio and gets the small plate }\end{array}$ & $\begin{array}{l}\text { Teller } \\
\text { plate }\end{array}$ & $\begin{array}{l}\text { Keks } \\
\text { cookie }\end{array}$ & $\begin{array}{l}\text { Socken } \\
\text { sock }\end{array}$ \\
\hline Primed & $\begin{array}{l}\text { Der Junge sieht das Hemd und zählt die vielen } \\
\text { Knöpfe } \\
\text { The boy sees the shirt and counts the many buttons }\end{array}$ & $\begin{array}{l}\text { Knöpfe } \\
\text { buttons }\end{array}$ & $\begin{array}{l}\text { Erbsen } \\
\text { peas }\end{array}$ & $\begin{array}{l}\text { Schlüssel } \\
\text { keys }\end{array}$ \\
\hline Neutral & $\begin{array}{l}\text { Der Junge sieht das Buch und zählt die vielen Knöpfe } \\
\text { The boy sees the book and counts the many buttons }\end{array}$ & $\begin{array}{l}\text { Knöpfe } \\
\text { buttons }\end{array}$ & $\begin{array}{l}\text { Erbsen } \\
\text { peas }\end{array}$ & $\begin{array}{l}\text { Schlüssel } \\
\text { keys }\end{array}$ \\
\hline Primed & $\begin{array}{l}\text { Der Junge sieht ein Haus und dann ein großes } \\
\text { Fenster } \\
\text { The boy sees a house and then a large window }\end{array}$ & $\begin{array}{l}\text { Fenster } \\
\text { window }\end{array}$ & $\begin{array}{l}\text { Bild } \\
\text { picture }\end{array}$ & $\begin{array}{l}\text { Auto } \\
\text { car }\end{array}$ \\
\hline Neutral & $\begin{array}{l}\text { Der Junge sieht einen Kuchen und dann ein großes } \\
\text { Fenster } \\
\text { The boy sees a cake and then a large window }\end{array}$ & $\begin{array}{l}\text { Fenster } \\
\text { window }\end{array}$ & $\begin{array}{l}\text { Bild } \\
\text { picture }\end{array}$ & $\begin{array}{l}\text { Auto } \\
\text { car }\end{array}$ \\
\hline Primed & $\begin{array}{l}\text { Der Junge sucht die Schere und sieht die großen } \\
\text { Buntstifte } \\
\text { The boy looks for the scissors and sees the large colored } \\
\text { pencils }\end{array}$ & $\begin{array}{l}\text { Buntstifte } \\
\text { Colored } \\
\text { pencils }\end{array}$ & $\begin{array}{l}\text { Pommes } \\
\text { French } \\
\text { fries }\end{array}$ & $\begin{array}{l}\text { Nüsse } \\
\text { Nuts }\end{array}$ \\
\hline Neutral & $\begin{array}{l}\text { Der Junge sucht die Hose und sieht die großen } \\
\text { Buntstifte } \\
\text { The boy looks for the pants and sees the large colored } \\
\text { pencils }\end{array}$ & $\begin{array}{l}\text { Buntstifte } \\
\text { Colored } \\
\text { pencils }\end{array}$ & $\begin{array}{l}\text { Pommes } \\
\text { French } \\
\text { fries }\end{array}$ & $\begin{array}{l}\text { Nüsse } \\
\text { Nuts }\end{array}$ \\
\hline
\end{tabular}




\section{References}

Altmann, G., \& Kamide, Y. (1999). Incremental interpretation at verbs: Restricting the domain of subsequent reference. Cognition, 73, 247-264.

Altmann, G., \& Mirković, J. (2009). Incrementality and prediction in human sentence processing. Cognitive Science, 33, 583-609.

Arias-Trejo, N., \& Plunkett, K. (2009). Lexical priming effects during infancy. Philosophical Transactions of the Royal Society B: Biological Sciences, 364, 3633-3647.

Arias-Trejo, N., \& Plunkett, K. (2010). The effects of perceptual similarity and category membership on early word-referent identification. Journal of Experimental Child Psychology, 105, 63-80.

Bloom, L. (1973). One word at a time: The use of single word utterances before syntax. The Hague, Netherlands: Mouton.

Booth, A. E., \& Waxman, S. R. (2002a). Object names and object functions serve as cues to categories for infants. Developmental Psychology, 38, 948-957.

Booth, A. E., \& Waxman, S. R. (2002b). Word learning is "smart": Evidence that conceptual information affects preschoolers' extension of novel words. Cognition, 84, B11-B22.

Borgström, K., von Koss Torkildsen, J., \& Lindgren, M. (2015). Event-related potentials during word mapping to object shape predict toddlers' vocabulary size. Frontiers in Psychology, 6. http://dx.doi.org/10.3389/fpsyg.2015.00143.

Bowerman, M. (1978). The acquisition of word meaning. In N. Waterson \& C. Snow (Eds.), Development of communication: Social and pragmatic factors in language acquisition. New York: John Wiley.

Chang, F., Dell, G. S., \& Bock, K. (2006). Becoming syntactic. Psychological Review, 113, 234-272.

Clark, E. V. (1973). What's in a word? On the child's acquisition of semantics in his first language. In T. Moore (Ed.), Cognitive development and the acquisition of language (pp. 65-110). New York: Academic Press.

Colunga, E., \& Smith, L. B. (2008). Knowledge embedded in process: The self-organization of skilled noun learning. Developmental Science, 11, 195-203.

DeLong, K. A., Urbach, T. P., \& Kutas, M. (2005). Probabilistic word pre-activation during language comprehension inferred from electrical brain activity. Nature Neuroscience, 8, 1117-1121.

Diesendruck, G., \& Bloom, P. (2003). How specific is the shape bias? Child Development, 74, 168-178.

Dikker, S., \& Pylkkänen, L. (2011). Before the N400: Effects of lexical-semantic violations in visual cortex. Brain and Language, $118,23-28$

Federmeier, K. D. (2007). Thinking ahead: The role and roots of prediction in language comprehension. Psychophysiology, 44, 491-505.

Gershkoff-Stowe, L., \& Smith, L. B. (2004). Shape and the first hundred nouns. Child Development, 75, 1098-1114.

Graham, S. A., \& Diesendruck, G. (2010). Fifteen-month-old infants attend to shape over other perceptual properties in an induction task. Cognitive Development, 25, 111-123.

Graham, S. A., Williams, L. D., \& Huber, J. F. (1999). Preschoolers' and adults' reliance on object shape and object function for lexical extension. Journal of Experimental Child Psychology, 74, 128-151.

Huettig, F. (2015). Four central questions about prediction in language processing. Brain Research, 1626, 118-135.

Huettig, F., \& Altmann, G. T. (2007). Visual-shape competition during language-mediated attention is based on lexical input and not modulated by contextual appropriateness. Visual Cognition, 15, 985-1018.

Huettig, F., \& Altmann, G. T. (2011). Looking at anything that is green when hearing "frog": How object surface colour and stored object colour knowledge influence language-mediated overt attention. Quarterly Journal of Experimental Psychology, 64, $122-145$.

Huettig, F., \& McQueen, J. M. (2007). The tug of war between phonological, semantic, and shape information in languagemediated visual search. Journal of Memory and Language, 57, 460-482.

Huettig, F., \& McQueen, J. M. (2011). The nature of the visual environment induces implicit biases during language-mediated visual search. Memory \& Cognition, 39, 1068-1084.

Huettig, F., Mishra, R. K., \& Olivers, C. N. (2012). Mechanisms and representations of language-mediated visual attention. Frontiers in Psychology, 2. http://dx.doi.org/10.3389/fpsyg.2011.00394.

Johnson, E. K., \& Huettig, F. (2011). Eye movements during language-mediated visual search reveal a strong link between overt visual attention and lexical processing in 36-month-olds. Psychological Research, 75, 35-42.

Johnson, E., McQueen, J. M., \& Huettig, F. (2011). Toddlers' language-mediated visual search: They need not have the words for it. Quarterly Journal of Experimental Psychology, 64, 1672-1682.

Kemler Nelson, D. G. (1995). Principle-based inferences in young children's categorization: Revisiting the impact of function on the naming of artifacts. Cognitive Development, 10, 347-380.

Kemler Nelson, D. G., Russell, R., Duke, N., \& Jones, K. (2000). Two-year-olds will name artifacts by their functions. Child Development, 71, 1271-1288.

Landau, B., Smith, L. B., \& Jones, S. S. (1988). The importance of shape in early lexical learning. Cognitive Development, 3, $299-321$.

Lew-Williams, C., \& Fernald, A. (2007). Young children learning Spanish make rapid use of grammatical gender in spoken word recognition. Psychological Science, 18, 193-198.

Mani, N., \& Huettig, F. (2012). Prediction during language processing is a piece of cake-But only for skilled producers. Journal of Experimental Psychology: Human Perception and Performance, 38, 843-847.

Mani, N., Johnson, E., McQueen, J. M., \& Huettig, F. (2013). How yellow is your banana? Toddlers' language-mediated visual search in referent-present tasks. Developmental Psychology, 49, 1036-1044.

Mani, N., \& Plunkett, K. (2007). Phonological specificity of vowels and consonants in early lexical representations. Journal of Memory and Language, 57, 252-272.

Mani, N., \& Plunkett, K. (2010). In the infant's mind's ear: Evidence for implicit naming in 18-month-olds. Psychological Science, 21, 908-913.

Mani, N., \& Plunkett, K. (2011). Phonological priming and cohort effects in toddlers. Cognition, 121, 196-206.

Mani, N., \& Schneider, S. (2013). Speaker identity supports phonetic category learning. Journal of Experimental Psychology: Human Perception and Performance, 39, 623-629. 
McQueen, J. M., \& Huettig, F. (2014). Interference of spoken word recognition through phonological priming from visual objects and printed words. Attention, Perception, \&' Psychophysics, 76, 190-200.

Meints, K., \& Woodford, A. (2008). Lincoln Infant Lab Package 1.0: A new programme package for IPL, preferential listening, habituation, and eyetracking. http://www.lincoln.ac.uk/home/media/universityoflincoln/schoolofpsychology/Handbook_0812-2009.pdf.

Merriman, W. E., Scott, P. D., \& Marazita, J. (1993). An appearance-function shift in children's object naming. Journal of Child Language, 20, 101-118.

Meyer, A. S., Belke, E., Telling, A. L., \& Humphreys, G. W. (2007). Early activation of object names in visual search. Psychonomic Bulletin E Review, 14, 710-716.

Pickering, M. J., \& Garrod, S. (2007). Do people use language production to make predictions during comprehension? Trends in Cognitive Sciences, 11, 105-110.

Pickering, M. J., \& Garrod, S. (2013). An integrated theory of language production and comprehension. Behavioral and Brain Sciences, 36, 329-347.

Rommers, J., Meyer, A. S., \& Huettig, F. (2015). Verbal and nonverbal predictors of language-mediated anticipatory eye movements. Attention, Perception, \& Psychophysics, 77, 720-730.

Rommers, J., Meyer, A. S., Praamstra, P., \& Huettig, F. (2013). The contents of predictions in sentence comprehension: Activation of the shape of objects before they are referred to. Neuropsychologia, 51, 437-447.

Rosch, E., Mervis, C. B., Gray, W. D., Johnson, D. M., \& Boyes-Braem, P. (1976). Basic objects in natural categories. Cognitive Psychology, 8, 382-439.

Samuelson, L. K., \& Smith, L. B. (1999). Early noun vocabularies: do ontology, category structure and syntax correspond? Cognition, 73, 1-33.

Samuelson, L. K., \& Smith, L. B. (2005). They call it like they see it: Spontaneous naming and attention to shape. Developmental Science, 8, 182-198.

Smith, L. B., Jones, S. S., \& Landau, B. (1996). Naming in young children: A dumb attentional mechanism? Cognition, 60, $143-171$.

Smith, L., Yu, C., Yoshida, H., \& Fausey, C. M. (2015). Contributions of head-mounted cameras to studying the visual environments of infants and young children. Journal of Cognition and Development, 16, 407-419.

Swingley, D., Pinto, J. P., \& Fernald, A. (1999). Continuous processing in word recognition at 24 months. Cognition, 71, 73-108.

Wicha, N. Y., Moreno, E. M., \& Kutas, M. (2004). Anticipating words and their gender: An event-related brain potential study of semantic integration, gender expectancy, and gender agreement in Spanish sentence reading. Journal of Cognitive Neuroscience, 16, 1272-1288.

Wilcox, T., \& Chapa, C. (2004). Priming infants to attend to color and pattern information in an individuation task. Cognition, 90, 265-302.

Wilcox, T., Woods, R., \& Chapa, C. (2008). Color-function categories that prime infants to use color information in an object individuation task. Cognitive Psychology, 57, 220-261.

Yeung, H. H., \& Nazzi, T. (2014). Object labeling influences infant phonetic learning and generalization. Cognition, 132, $151-163$.

Yeung, H. H., \& Werker, J. F. (2009). Learning words' sounds before learning how words sound: 9-month-olds use distinct objects as cues to categorize speech information. Cognition, 113, 234-243.

Yu, C., \& Smith, L. B. (2013). Joint attention without gaze following: Human infants and their parents coordinate visual attention to objects through eye-hand coordination. PLOS ONE, 8(11), e79659. 